\title{
STUDIES OF ICE MOVEMENTS ON THE WARD HUNT ICE SHELF BY MEANS OF TRIANGULATION-TRILATERATION
}

\author{
G. Konecny ${ }^{1}$ and W. Faig ${ }^{2}$
}

\begin{abstract}
A method is described by which accurate measurements of ice movements were performed on the Ward Hunt Ice Shelf at Ward Hunt Island. Geodimeter distance measurements and angular theodolite measurements were combined in a system of triangulationtrilateration in the form of a chain of quadrilaterals to achieve relative positioning accuracies of \pm 1 to $2 \mathrm{~cm}$. for the survey markers drilled into the shelf ice.

Shelf ice movements of $30 \mathrm{~cm}$. with respect to solid ground were obtained between 1964 and 1965. The relative position change between the markers on shelf ice was less than $4 \mathrm{~cm}$. Experience on this first known arctic application of the geodimeter are reported.
\end{abstract}

RESUME. Etudes des mouvements de la glace de la barrière de Ward Hunt, au moyen de la triangulation et de la trilatéralisation. Les auteurs décrivent une méthode par laquelle ils ont établi des mesures précises des mouvements de la glace sur la barrière de l'île de Ward Hunt. Ils ont combiné des mesures de distance au géodimètre et des mesures angulaires au théodolite en un système de triangulation et de trilatéralisation, sous forme d'une chaîne de tétragones, avec une précision de l'ordre de \pm 1 à $2 \mathrm{~cm}$. dans la localisation relative des repères forés dans la glace de la barrière.

Entre 1964 et 1965 , on a observé des mouvements de $30 \mathrm{~cm}$. de la glace par rapport à la terre ferme. Les déplacements des repères sur la glace ont été inférieurs à $4 \mathrm{~cm}$. Il s'agit de la première utilisation connue du géodimètre dans l'Arctique.

АБСТРАКТ. ИЗУЧЕНИЕ ДВИЖЕНИЙ ЛЬДА НА ЛЕДЯНОМ ШЕЛЬФЕ УОРА-ХАНТ ПОСРЕДСТВОМ ТРИАНГУЛЯЦИИ И ТРИЛАТЕРАЦИИ. ОПИСЫВается МеТОД, ПОСРЕДСТВОМ которого было произведено точное измерение движения льда на ледяном шельфе острова Уорд-Хант. Для получения относительного положения вмороженных в ледяной пельф вепек с точностью $\pm 1-2$ см., расстояния измеренные теодиметром и угловые триангуляционные измерения теодолитом были увязаны в триангудяционно-трилатерационную систему в виде цепи четырехугольников.

Между 1964 и 1965 годом было отмечено продвижение дьда в 30 см. по отношению к ледовому грунту. Изменение относительного положения отметочных велек было на шельфовом льду меньше 4 см. Ошисывается опыт первого иввестного применения геодиметра в Арктике.

\section{Introduction}

$\mathbf{T}$

HE ICE SHELF along the northern coast of Ellesmere Island has been subject to numerous scientific investigations during the past fifteen years. In a central location, surrounded by more than $2000 \mathrm{~km} .^{2}$ of ice shelf, Ward Hunt Island is located at approximately $74^{\circ} \mathrm{W} ., 83^{\circ} 06^{\prime} \mathrm{N}$. An ice rise, i.e. grounded ice, extends about $1 \mathrm{~km}$. to the east and approximately $5 \mathrm{~km}$. to the north and to the west of the island. The adjoining parts of the ice shelf consist of floating ice, separated from the ice rise by tide cracks.

The ice shelf, which is 40 to $50 \mathrm{~m}$. thick is subject to continuous changes due to the action of various forces, such as movements of the ice shelf in relation to the land, pressure of land glaciers, especially in the fiords, temperature changes, tidal action, pressure of pack ice and wind action. The ice shelf has ridges and troughs with elevation differences of about 5 to $10 \mathrm{~m}$. (Hattersley-Smith 1957).

${ }^{1}$ Head, Department of Surveying Engineering, University of New Brunswick.

2Research Assistant, Department of Surveying Engineering, University of New Brunswick. 
The most obvious changes are the large calvings, which are the source of most of the ice islands drifting in the Arctic Ocean (Crary 1958). The most recent Ward Hunt ice-shelf calving occurred during the winter 1961-62, forming 5 large and numerous small ice islands (with an area of up to $180 \mathrm{~km} .{ }^{2}$ ).

Various methods may be employed to evaluate critical conditions governing growth, motion, and break-up of shelf ice in the Arctic. Climatic and meteorological studies, ablation-accumulation observations, seismic depth measurements, tidal recordings, ice temperature measurements, as well as investigations by ordinary survey methods to obtain position and elevation data have been carried out in the area.

In 1954 a transit level survey was made from the mainland shore to the ice front on a south-north line, about $1 \frac{1}{2} \mathrm{~km}$. west of Ward Hunt Island (HattersleySmith et al. 1955). The main purpose was to obtain height information in the form of a profile.

In 1959, and again in 1960 a research program of the Arctic Institute of North America was conducted in the area. In addition to the various scientific studies undertaken in 1959, a survey line for height information was established from the mainland to the edge of the ice shelf, about $10 \mathrm{~km}$. west of Ward Hunt Island. A resurvey was made in 1960, and a number of level lines were carried across the shelf (Sagar 1960). These in turn were resurveyed by a party of the Canadian Defence Research Board in 1963 by inaccurate triangulation methods, compared with those of the original surveys. This study was intended to detect changes in horizontal and vertical position in the three-year period, but the strain rate on the ice shelf appeared to be so low that methods more accurate than crude triangulation and chaining were considered necessary (Hattersley-Smith 1964).

Therefore the Department of Surveying Engineering of the University of New Brunswick was invited to perform a survey of higher accuracy on floating ice in 1964, and a resurvey in 1965 was to provide horizontal data on internal motion as well as on shifts in relation to the land. On floating ice larger movements were expected and a precise survey method was to be chosen.

\section{Survey}

There are several ways of performing such a survey: the configurations may vary from traverses to the survey of triangle land quadrilateral chains established by triangulation, trilateration, and a combination of both. While traversing does not provide the desirable checks, triangulation and trilateration accuracy depends greatly upon the strength of the geometrical configuration of the net. As previously mentioned, the ice shelf has ridges and troughs, and therefore it is practically impossible to obtain ideal configurations. Thus it was decided to extend control in the form of a quadrilateral chain in which both distances and directions were to be measured.

For the selection of suitable instruments, accuracy requirements as well as weather conditions had to be considered. The main problem consisted in finding an appropriate distance measuring device. As conventional survey procedures such as chaining and subtense bar measurement would not meet the accuracy requirements, electronic-optical instruments had to be used. Because of the frequent fog in the area the tellurometer appeared to be best suited from the point of view of convenience. It has, however, an inferior absolute and relative 
accuracy compared to the geodimeter. To avoid sacrificing this possible accuracy increase, the geodimeter was chosen as the distance-measuring device, but because of the special conditions in the Arctic several difficulties were encountered. The constant daylight conditions made it necessary to use the geodimeter model NASM 4D with a mercury lamp. This attachment enables daylight measurements up to 5 miles in southern areas. In the light conditions due to snow and atmosphere it became possible to operate only on days with good visibility. Even then, bright sunshine and the reflection of the snow limited its range considerably. The maximum distance measured under these conditions with a geodimeter model 4D (with mercury lamp) was $21 / 2 \mathrm{~km}$. To reach this distance a special arrangement had to be used: a black screen was mounted behind a 21-prism reflector combination. The size of this screen was determined by the space between the two Kerr cell electrodes in the geodimeter scope. It must be completely covered by the black area in order to receive the modulated light which is the basis of electronic distance measurement by phase comparison from the reflector prisms. The observation accuracy was about $\pm 1 \mathrm{~cm}$. which corresponds to the angular observation accuracy of approximately \pm 3 seconds obtained with the T-2 theodolite over the usual distances of $1 \mathrm{~km}$., particularly as the angular observations were carried out in three sets. Thus angular observations had equal weight with distance observations, and therefore the point accuracy became independent of the geometrical shape of the net (Chrzanowski and Konecny 1965).

The net was established as shown in Fig. 1. The rock stations were marked with brass plugs, the ice stations with aluminum pipes, which were drilled about $2 \mathrm{~m}$. deep into the ice. In 1964 they were placed at an exact height of $1.30 \mathrm{~m}$. above ice level. In this way the instruments could be set up centrically over the station, and an exact reference value for further ablation-accumulation measurements was established. To find the pipes for angular observations they were marked by bamboo poles $4 \mathrm{~m}$. long carrying cloth flags. The poles were fitted into the pipes. With one exception, they were all in good condition in 1965. As indicated in Fig. 1, because of foggy weather not all the distances in the net could be measured. The quadrilateral of main interest however, was completely surveyed in both years.

\section{Computations}

For the calculations, a local coordinate system was chosen with point 13 (Fig. 1) as origin. The direction 13-11 served as negative $y$-axis, thus giving the net an approximate north orientation.

Fig. 1. Ward Hunt ice shelf quadrilateral net.

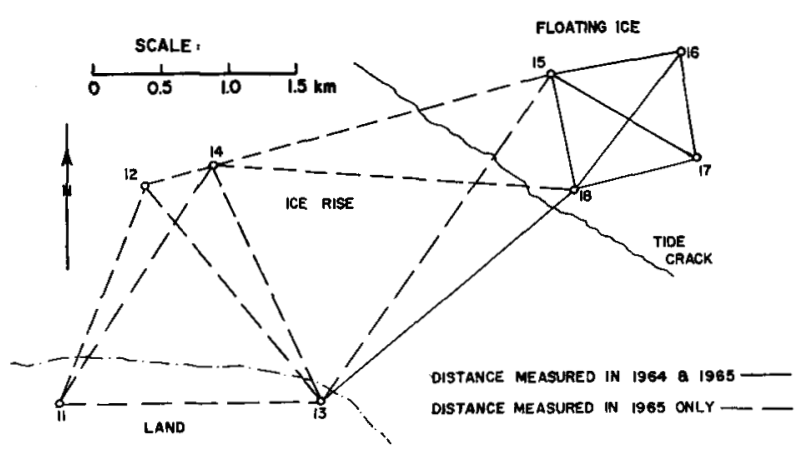


Theoretically two separate adjustments of the 1964 and 1965 surveys should present the ice movements in the form of coordinate differences. However, owing to bad weather it was impossible in 1964 to measure a sufficient number of distances to ensure this (Fig. 1), and as this might have an influence on the scale of the connecting net, it was decided to perform a complete adjustment of the 1965 survey only. This provided the necessary coordinate frame. An adjustment of the quadrilateral, points 15 to 18 with respect to point 13 , using the 1964 observations, gave the desired coordinate differences caused by ice movements. As it was of special interest to obtain data on surface strain, the influences due to shifting along the tide-crack were eliminated by performing separate adjustments of the quadrilateral, points 15 to 18 for both years.

All adjustments were performed on an IBM 1620 computer, using the least squares observation equation method. Because the influence of centring errors was not known all error equations were taken with unit weight.

\section{Results}

Table 1 shows the 1965 coordinates with their standard errors for the whole net. The standard error is less than $\pm 1 \mathrm{~cm}$. for every coordinate value, which proves that the objectives of the survey were met.

Table 1. Coordinates and their standard errors as obtained from the 1965 survey.

\begin{tabular}{lrrrr}
\hline POINT & \multicolumn{1}{c}{$\mathrm{x}[\mathrm{m}]$} & \multicolumn{1}{c}{$\mathrm{m}_{\mathbf{x}}[\mathrm{m}]$} & $\mathrm{y}[\mathrm{m}]$ & $\mathrm{m}_{\mathrm{y}}[\mathrm{m}]$ \\
\hline 11 & $-1,951.27$ & \pm 0.006 & 0.00 & \\
12 & $-1,300.81$ & \pm 0.006 & $1,618.36$ & \pm 0.005 \\
13 & 0.00 & & 0.00 & \\
14 & -789.84 & \pm 0.005 & $1,758.96$ & \pm 0.005 \\
15 & $1,712.89$ & \pm 0.006 & $2,415.65$ & \pm 0.006 \\
16 & $2,671.26$ & \pm 0.007 & $2,557.83$ & \pm 0.008 \\
17 & $2,826.83$ & \pm 0.006 & $1,760.11$ & \pm 0.007 \\
18 & $1,877.28$ & \pm 0.005 & $1,522.51$ & \pm 0.006 \\
\hline
\end{tabular}

In Table 2 the results of the 1964 survey are shown. Here the standard error is considerably greater, which is caused by the relatively weak connection to the land. A comparison of the surveys for 1964 and 1965 also showed that there was no movement exceeding the accuracy of the 1964 survey for points 12 and 14 , both located on a grounded ice rise.

For the determination of internal movements of points 15 to 18 , corrections for the approximate coordinates of the points 16 to 18 were computed, leaving the relative position of point 15 fixed. These differences with their standard errors, as obtained with the observations of both years are listed in Table 3. These show that the survey accuracy within the quadrilateral 15 to 18 are in the magnitude of \pm 1 to $2 \mathrm{~cm}$. also.

Table 2. Coordinates and their standard errors as obtained from the 1964 survey.

\begin{tabular}{lrrrr}
\hline POINT & \multicolumn{1}{c}{$\mathrm{x}[\mathrm{m}]$} & $\mathrm{mx}[\mathrm{m}]$ & $\mathrm{y}[\mathrm{m}]$ & $\mathrm{my}[\mathrm{m}]$ \\
\hline 13 & 0.00 & & 0.00 & \\
15 & $1,713.04$ & \pm 0.09 & $2,415.48$ & \pm 0.09 \\
16 & $2,671.53$ & \pm 0.09 & $2,557.66$ & \pm 0.08 \\
17 & $2,827.04$ & \pm 0.09 & $1,759.95$ & \pm 0.08 \\
18 & $1,877.49$ & \pm 0.09 & $1,522.38$ & \pm 0.08 \\
\hline
\end{tabular}


Table 3. Corrections with their Standard Errors in the Quadrilateral on Floating Ice.

1964

\begin{tabular}{lcccc}
\hline POINT & $\Delta \mathrm{x}[\mathrm{m}]$ & $\mathrm{m} \Delta \mathrm{x}[\mathrm{m}]$ & $\Delta \mathrm{y}[\mathrm{m}]$ & $\mathrm{m} \Delta \mathrm{y}[\mathrm{m}]$ \\
\hline 15 & 0.00 & & 0.000 & \\
16 & -0.003 & \pm 0.012 & -0.043 & \pm 0.009 \\
17 & +0.015 & \pm 0.012 & -0.0004 & \pm 0.012 \\
18 & -0.025 & \pm 0.009 & +0.001 & \pm 0.012 \\
\hline & & & & \\
\hline POINT & $\Delta \mathrm{x}[\mathrm{m}]$ & 1965 & $\Delta \mathrm{y}[\mathrm{m}]$ & $\mathrm{m} \Delta \mathrm{y}[\mathrm{m}]$ \\
\hline 15 & 0.000 & $\mathrm{~m} \Delta \times[\mathrm{m}]$ & 0.000 & \\
16 & -0.106 & & +0.030 & \pm 0.008 \\
17 & -0.020 & \pm 0.011 & -0.025 & \pm 0.010 \\
18 & -0.003 & \pm 0.011 & -0.090 & \pm 0.010 \\
\hline
\end{tabular}

The resulting ice movements are represented by the coordinated differences. The total motion, (differences between values of 1 and 2) shows a definite shift of the floating ice along the tide crack of $26 \mathrm{~cm}$. The influence of internal motions is hardly noticeable, except perhaps along the line 15-16 (Table 4 and Fig. 2).

The differences between the corrections obtained by the independent adjustments of the quadrilateral are shown in Table 5 and Fig. 3. There does not seem to be a special pattern. The movements vary in direction and in magnitude from 5 to $11 \mathrm{~cm}$.

Fig. 2. Shift along tide crack.

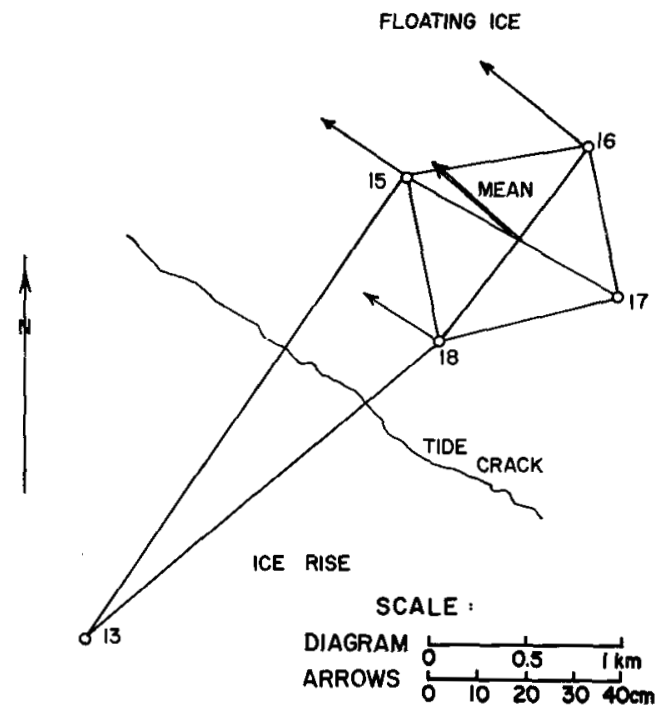

Table 4. Coordinate differences, indicating total movements.

\begin{tabular}{ccc}
\hline POINT & $\mathrm{x}_{\text {I966 }}-\mathrm{x}_{1964}[\mathrm{~m}]$ & $\mathrm{y}_{1965}-\mathrm{y}_{1964}[\mathrm{~m}]$ \\
\hline 15 & -0.15 & +0.17 \\
16 & -0.27 & +0.17 \\
17 & -0.21 & +0.16 \\
18 & -0.21 & +0.13 \\
MEAN & -0.21 & +0.16 \\
\hline
\end{tabular}


The accuracy achieved in this work shows that the chosen survey method as well as the chosen instruments meet the requirements for such a project. A resurvey of the same net should provide further valuable information on the ice movements.

The fact that only a very slight movement of ice was observed and that this movement is simply a shift of the ice along the tide crack would suggest that the ice shelf is in a stagnant condition. The surface strains tend to indicate the existence of an approximately E-W compression and a N-S elongation of the ice, but the strains are very small and measurements over a longer period of time will be needed before really reliable data on strain rates are obtained.

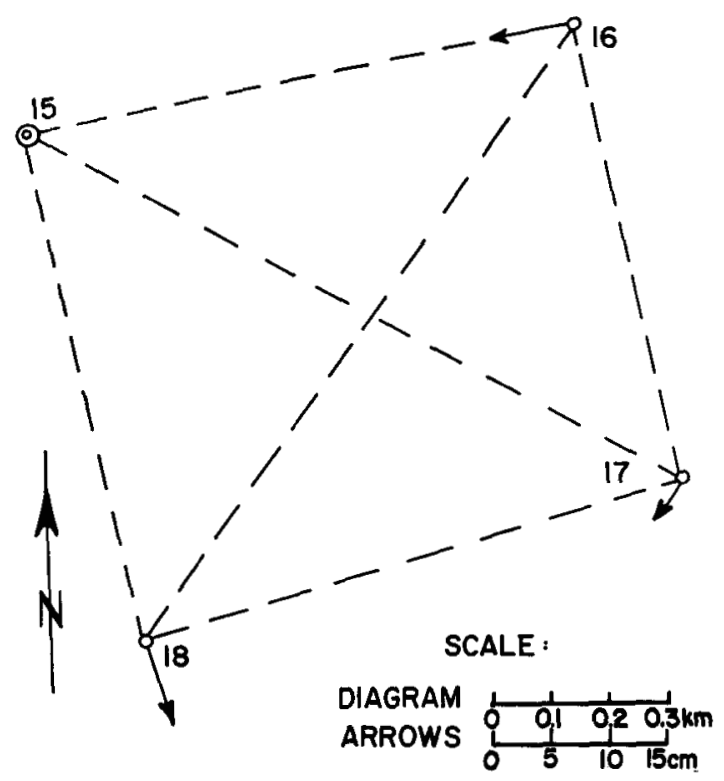

Fig. 3. Internal movements on floating ice.

Table 5. Correction differences, indicating internal motions.

\begin{tabular}{lcc}
\hline POINT & $\Delta \mathrm{x}_{1966}-\Delta \mathrm{x}_{1064}[\mathrm{~m}]$ & $\Delta \mathrm{y}_{1966}-\Delta \mathrm{y}_{1964}[\mathrm{~m}]$ \\
\hline 15 & 0.000 & 0.000 \\
16 & -0.103 & -0.013 \\
17 & -0.036 & -0.024 \\
18 & +0.021 & -0.090 \\
\hline
\end{tabular}

\section{References}

Chrzanowski, A. and G. Konecny. 1965. Theoretical comparison of triangulation, trilateration and traversing. Canadian Surveyor 19:353-66.

Crary, A. P. 1958. Arctic ice island and ice shelf studies. Arctic 11:3-42.

Hattersley-Smith, G. F. 1957. The rolls on the Ellesmere ice shelf. Arctic 10:32-44.

1964. Operation Hazen, Operation Tanquary: preliminary report, 1963. Ottawa:

Defence Research Board, Department of National Defence.

and others. 1955. Northern Ellesmere Island 1953 and 1954. Arctic 8:3-36.

Sagar, R. B. 1960. Ellesmere Island Ice Shelf Project 1960. Arctic 13:271-72. 